\title{
TROPHIC STATE INDEXES AND PHYTOPLANKTON IN THE TROPHIC STATUS ASSESSMENT OF WATERS OF A SMALL RETENTION RESERVOIR AT AN EARLY STAGE OF OPERATION
}

\author{
Magdalena Suchora', Agnieszka Szczurowska², Michał Niedźwiecki \\ 1 Department of Environmental Engineering and Geodesy, University of Life Sciences in Lublin, Leszczyńskiego \\ 7, 20-069 Lublin, Poland, magda.suchora@up.lublin.pl \\ 2 Department of Plant Physiology, University of Life Sciences in Lublin, Akademicka 15, 20-950 Lublin, Poland \\ 3 Department of Hydrobiology, University of Life Sciences in Lublin, Dobrzańskiego 37, 20-262 Lublin, Poland \\ * Corresponding author's e-mail: magda.suchora@up.lublin.pl
}

Received: 2017.05 .12

Accepted: 2017.08.01

Published: 2017.09.01

\begin{abstract}
This paper will focus on determining the trophic status of the two basins of the Niwa Reservoir - Niwa I and Niwa II (Sawin commune, Lubelskie Province, SE Poland) at the sixth year of operation, by using partial TSI indexes - TSI(SD), TSI(TP), TSI(chl-a), as well as qualitative and quantitative structures of phytoplankton. As a supplementary, index TSI(TOC) was employed. We show that the phytoplankton abundance, as well as TSI(chl-a) and TSI(TP) were relatively low and typical for mesotrophic waters (with the exception of July TSI(TP) values for the Niwa II basin), although the evaluation of trophy based on other partial TSI indexes - TSI(SD), TSI(TOC) pointed to a eutrophic or even a hypertrophic water characteristic. The obtained results were discussed in detail and referenced to other, non-nutrient related trophy factors: morphometric features and geology of the basins, as well as the physicochemical properties of its water.
\end{abstract}

Keywords: eutrophication, small retention reservoir, trophic state index, phytoplankton

\section{INTRODUCTION}

Small retention reservoirs are desirable elements of the agricultural landscape, as their presence contributes to a wide range of ecosystem services, including local biodiversity growth [Zedler, 2003]. Most of these reservoirs are designed as multifunctional, meaning, that apart from their essential function, i.e. water storage for hydration purposes and equalization of flows, they perform a number of other tasks. In contrary to large-volume dam reservoirs, the multi-functional character does not usually lead to conflict of interests. The most common problem concerning the quality of water of small retention reservoirs is eutrophication [Siemieniuk et al. 2016], symptoms of which may occur already in the first years of operation, and examples of rapid eutrophication are known from multiple research [e.g. Pawlik-Skowrońska and Toporowska 2011; Pęczuła and Suchora 2011]. This phenomenon, together with all its nagging/severe consequences (especially cyanobacteria blooms), is particularly acute if among assumed functions of the reservoir is a recreational use. Despite the prevalence of the problem, there is no requirement for the assessment of the eutrophication risk at the stage of planning and construction of small retention reservoirs [Cooke et al. 2005], and the problem is usually resolved when it becomes burdensome and limits further use. At this stage, all actions leading to improvement of the quality of water require labor and cost-conscious measures, and are only likely to be successful with in-depth understanding of the mechanisms and conditions of eutrophication of the particular reservoir [Popek 2015; Dunalska and Wiśniewski, 2016]. Still, the early recognition of the trophic status 
and regulatory mechanisms within the emerging ecosystem may contribute to extending the period of good water quality.

The aim of the study was the assessment of the trophic status of the Niwa Reservoir (Niwa I and Niwa II basins) based upon the seasonal measurements of physicochemical and biological parameters of water, as well as the phytoplankton composition. Analysis of partial TSI indexes and physicochemical parameters was the first assessment enabling the identification of the water quality factors of this shallow, small retention reservoir at the early stage of its operation.

\section{MATERIAL AND METHODS}

\section{Study area}

Niwa Reservoir (51 $16^{\prime} 23^{\prime \prime} \mathrm{N}, 23^{\circ} 23^{\prime} 54^{\prime \prime}$ E) is a small, lowland, flow-through retention reservoir of an agricultural catchment. It was constructed as a result of land works within the meliorated calcareous mire, and water-filled in 2010. The reservoir consists of two separate basins - Niwa I and Niwa II, of different morphometry (Table 1.), geology and water supply. The main basin, Niwa I, is supplied by the Lepietucha river, the water being brought by an underground pipe-feeder system, whereas the smaller, Niwa II reservoir is fed by water from the Nagórnik melioration ditch - draining the waters from the extensive peatland areas (Fig. 1.). Due to the undulated character of the mineral bedrock, the Niwa I basin is formed by the partial excavation of the upper layer of peat, whereas the Niwa II basin is dug entirely within the chalk elevation.

\section{Methods}

The water quality assessment of the Niwa Reservoir was based on field measurements and laboratory analysis of chemical and physical parameters, as well as the taxonomic composition and total phytoplankton abundance, and was car-

Table 1. Morphometric characteristics of the Niwa Reservoir (basins Niwa I and Niwa II)

\begin{tabular}{|l|c|c|}
\hline \multicolumn{1}{|c|}{ Parameter } & Niwa I & Niwa II \\
\hline Area, ha & 44.3 & 8.5 \\
\hline Normal Storage Level (NSL), m a.s.I & 176.50 & 174.80 \\
\hline Mean depth, m & 1.91 & 0.92 \\
\hline Water volume at NSL, $\mathrm{m}^{3}$ & 846475 & 77988 \\
\hline
\end{tabular}

ried out in 2016. The hydrochemical and phycological research were conducted bimonthly, during the vegetation season of 2016, from May to October, at several research points situated within the Niwa I and Niwa II basins. Due to the low diversity of the obtained results within each basin, resulting probably from good wind-mixing of waters, for the purpose of trophy assessment, only two representative research points situated at the central point of each basin were chosen (Fig. 1.).

Temperature, dissolved oxygen (DO), electrical conductivity (EC) and $\mathrm{pH}$ were determined in situ with a YSI 556 MPS multiparametric probe. Water transparency was determined with a Secchi disk. Other environmental variables were measured in the laboratory: total suspended solids (TSS), total organic carbon (TOC), biochemical oxygen demand (BOD) and chemical oxygen demand (COD) using a PASTEL UV spectrophotometer (Secomam, France); total phosphorus $\left(\mathrm{P}_{\text {tot }}\right)$ and dissolved ortho-phosphorus $\left(\mathrm{P}-\mathrm{PO}_{4}\right)$ with a Schimadzu UV-1610 spectrophotometer (by the molybdate method after mineralization with a mixture of $\mathrm{HNO}_{3}$ and $\mathrm{H}_{2} \mathrm{SO}_{4}$ ); and nitrate nitrogen $\mathrm{N}-\mathrm{NO}_{3}$ by the sodium salicylate method. Chlorophyll a (chl-a) was determined spectrophotometrically after extraction with ethanol [Yentsch and Menzel, 1963]. At one time (October), the calcium concentration was determined using the titration method. The changes in the water level was noted from the gauge located in the NE part of the Niwa I reservoir.

Simultaneously to the water chemistry, samples for the analysis of phytoplankton were taken. Due to the minimal depth, water samples for quantitative phytoplankton analysis were collected from the surface layer $(\sim 0.5 \mathrm{~m})$ with the double use of the $5 \mathrm{dm}^{3}$ sampler. Herein, ten liters of water were filtered through plankton net (mesh size: $25 \mu \mathrm{m}$ ), and fixed with Lugol solution. The additional samples were taken for proper identification of species in live samples. Identification and enumeration were performed using an inverted microscope and the Utermöhl method [1953].

To estimate trophic status, we have calculated Trophic State Index (TSI) [Carlson 1977] using water transparency TSI(SD), concentration of chlorophyll a TSI(chl-a) and total phosphorous TSI(TP). Additionally, due to emerging tendency towards including the dissolved organic carbon (DOC) into trophic state indicators for lakes [Dunalska 2011] and reservoirs [Lee et al. 2014], as an auxiliary indicator, we employed the trophic 


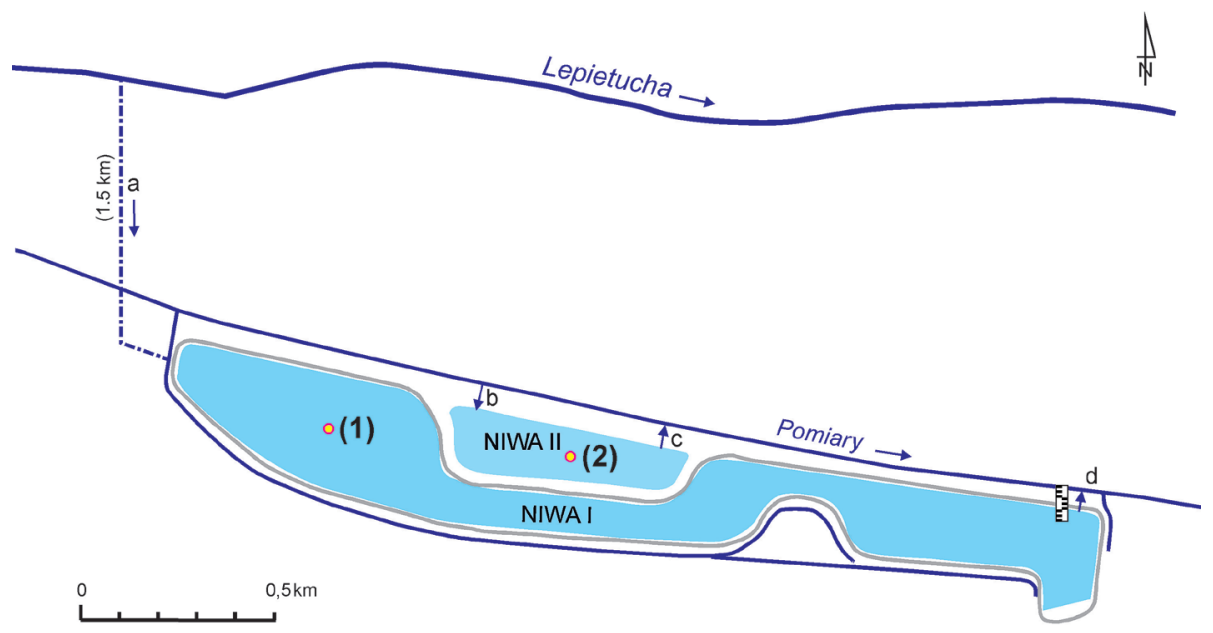

Fig. 1. Situation map of the Niwa Reservoir and location of the sampling sites (1-2) within Niwa I and Niwa II sub-basins, a - underground inlet, b-inlet, c, d-outlets

state index based on total organic carbon concentration - TSI(TOC) calculated according to the formula TSI $(\mathrm{TOC})=20.59+15.71 \ln (\mathrm{TOC})$ [Dunalska 2011].

\section{RESULTS}

\section{Environmental variables}

Water of the both basins of the Niwa Reservoir were alkaline $(\mathrm{pH}$ at Niwa I ranged from 8.07 to 8.48 , and at Niwa II, from 7.90 to 8.40 ) and highly mineralized (electrolytic conductivity: Niwa I 385-439 $\mu \mathrm{S} \cdot \mathrm{cm}-1$, Niwa II 439-467 $\mu \mathrm{S} \cdot \mathrm{cm}-1)$. Oxygen content within both basins were high (over 100\% and 8.73-9.70 $\mathrm{mg} \cdot \mathrm{dm}^{-3}$ ) during the whole season. Values of the chlorophyll-a concentrations ranged from 2.16 to 5.79 $\mu \mathrm{g} \cdot \mathrm{dm}^{-3}$ at Niwa I (with summer maximum), and 2.85 to $4.56 \mu \mathrm{g} \cdot \mathrm{dm}^{-3}$ at Niwa II (maximum value noted at autumn). The remarkable difference during the whole observation period was noted for the water transparency parameter, ranging from 1.27 to 1.60 at Niwa I, and from 0.30 to $0.45 \mathrm{~m}$ at Niwa II (Table 1), which was also in agreement with the values of the total suspended solids (below $2.5 \mathrm{mg} \cdot \mathrm{dm}^{-3}$ and 5.5 to 21.1 , respectively). Regarding the low values of the chlorophyll $a$, the high turbidity at Niwa II should be attributed to the mineral (abioseston) component, derived from the calcareous bottom. The elevated values of nitrates, as well as TOC, BOD and COD, were noted at the time of the spring (seasonal) filling of the Niwa I reservoir, which was related to the influence of the nutrient and organic matter load of the Lepietucha waters.

\section{Phytoplankton}

A qualitative analysis of phytoplankton showed, in total, 64 pro- and eukaryotic algal taxa belonging to eight taxonomical groups. In the two basins, although the general taxonomic structures were similar, there were substantial differences in species composition. In the Niwa I basin, we identified 31 taxa belonging to 6 taxonomic groups, whereas in Niwa II, 45 taxa from 8 groups were encountered. For both basins, the most identified taxa belonged to green algae and cyanobacteria - at Niwa I, they accounted for $42 \%$ and $26 \%$ of the whole, respectively, and Niwa II, $39 \%$ and $22 \%$, respectively. The diatoms also had a major contribution to the taxonomic structure, representing at Niwa I, 16\%, and Niwa II, $18 \%$ of the total taxa within the phytoplankton communities. The proportion of other systematic groups of phytoplankton did not exceed $10 \%$ of the total number of identified taxa (Fig. 2).

The seasonal dynamics of phytoplankton were similar in the Niwa I and Niwa II basins, with a lasting, high proportion of Chlorophyta, Cyanoprokaryota and Bacillariophyceae, a higher share of diatoms being typical for the spring period (Fig. 3).

The total phytoplankton abundance at Niwa I and Niwa II basins were comparable within the seasons, with spring minima $\left(150.6 \times 10^{3} \mathrm{ind} \cdot \mathrm{dm}^{-3}\right.$ and $120.3 \times 10^{3}$ ind. $\cdot \mathrm{dm}^{-3}$, 
a)

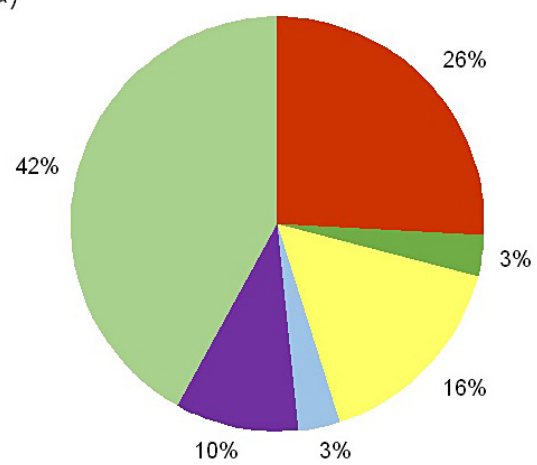

b)

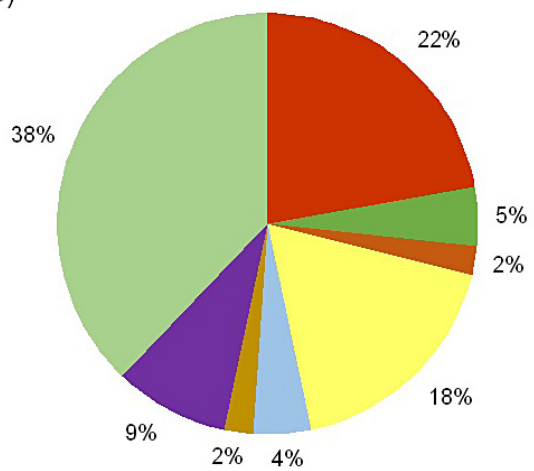

- Cyanoprokaryota

@ Chrysophyceae

Xanthophyceae

Bacillariophyceae

- Cryptophyta

Dinophyta

घ Euglenophyta

Chlorophyta

Fig. 2. The percentage contribution of the taxonomic groups of algae in phytoplankton of the Niwa I and Niwa II basins, in 2016

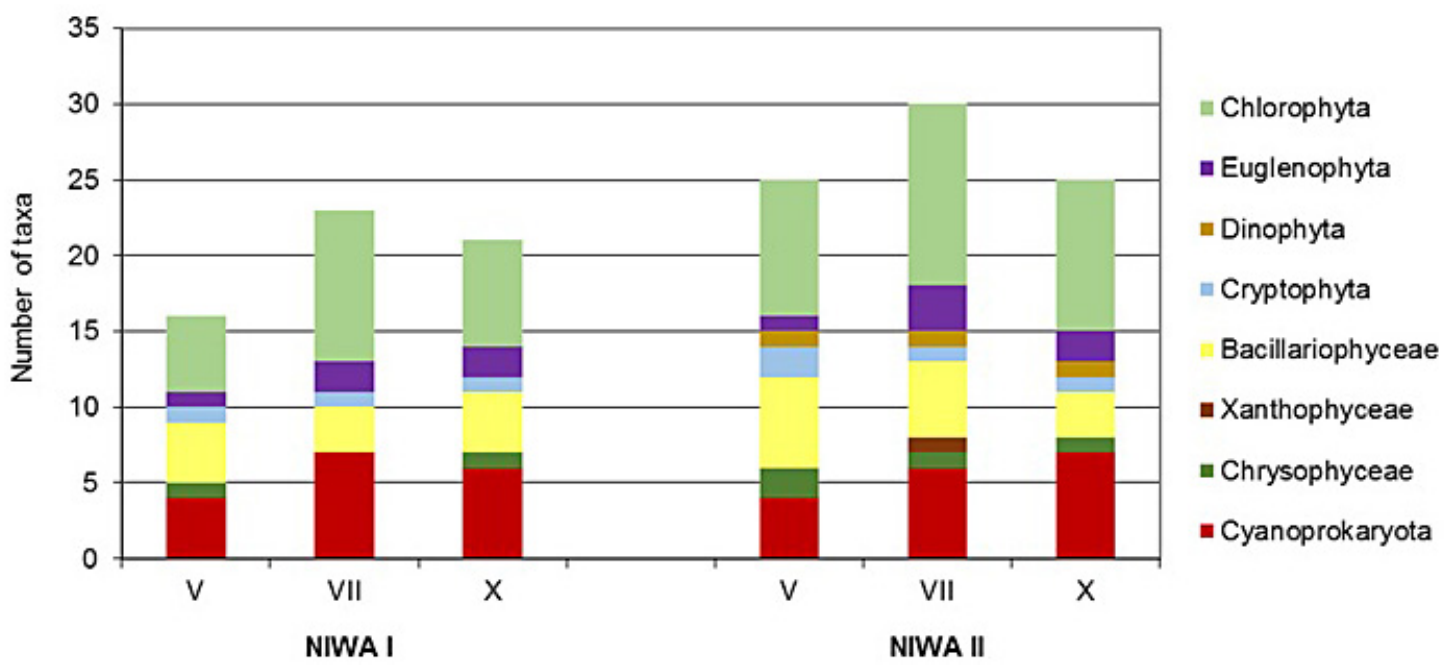

Fig. 3. Seasonal changes of taxonomic structure of phytoplankton in Niwa I and Niwa II basins, in 2016

respectively). The highest abundance for the Niwa I basin was noted in July $\left(593 \times 10^{3}\right.$ ind. $\left.\cdot \mathrm{dm}^{-3}\right)$, whereas at Niwa II, this was evident in October $\left(610 \times 10^{3}\right.$ ind. $\cdot \mathrm{dm}^{-3}$, Table 2$)$. The highest share of total autumn phytoplankton in both basins was of Dinobryon divergens Imhof (Chrysophyceae). Other than the aforementioned, no other specie reached more than $50 \%$ of the total population in any of the study seasons. The autumn domination of this smallbodied species was the reason for discrepancy between the highest total phytoplankton abundance and the concentration of chlorophyll-a (which is an estimator of phytoplankton biomass, Regulation of the Minister of Environment 2004) at Niwa I (Table 2). In the Niwa II basin, taxa from dystrophic habitats - e.g. Closterium acutum var. variabile (Lemm.) Willi Krieg. - have been observed, which is associated with humic water supply.

\section{Trophic State Index}

The partial values of the Carlssons' Trophic State Indexes were very diversified. For both basins, the lowest values were typically recorded for TSI(chl-a), ranging from $40.9-47.8$ at Niwa I, and $19.2-45.5$ at Niwa II (Tab. 3, Fig. 4). Moreover, the TSI(TP) was low and typical to mesotrophy, with the exception of July TSI values for Niwa II basin. High values were noted for TSI(SD) - at Niwa I, the values ranged from 55.1 to 56.6 , whereas the values at Niwa II were between 71.5 to 77.4 , indicating eutrophy or hypertrophy, respectively. However, for the reservoirs, the TSI(SD) criteria is consider less reliable [Carlson, 1991]. In addition, high values of TSI(DOC) -54.5 to 62.0 at Niwa I and 52.5 to 53.4 at Niwa II, used here as an auxiliary indicator, might overestimate the trophy level, as it is yet not fully dedicated towards the estimation of 
Table 2. Basic hydrochemical and biological parameters of the Niwa Reservoir (basins Niwa I and Niwa II) in 2016

\begin{tabular}{|c|c|c|c|c|c|c|}
\hline \multirow{2}{*}{ Parameters } & \multicolumn{3}{|c|}{ Niwa I } & \multicolumn{3}{|c|}{ Niwa II } \\
\hline & May & July & October & May & July & October \\
\hline Water level & 91 & 49 & 40 & - & - & - \\
\hline Temperature, ${ }^{\circ} \mathrm{C}$ & 19.0 & 19.9 & 16.1 & 19.1 & 20.5 & 15.9 \\
\hline Transparency, m & 1.40 & 1.60 & 1.27 & 0.45 & 0.30 & 0.45 \\
\hline $\mathrm{pH}$ & 8.45 & 8.48 & 8.07 & 8.28 & 8.40 & 7.90 \\
\hline Conductivity, $\mu \mathrm{S} \mathrm{cm}^{-1}$ & 439 & 385 & 396 & 439 & 445 & 467 \\
\hline Dissolved oxygen, $\mathrm{mg} \mathrm{dm}^{-3}$ & 9.28 & 8.73 & 9.46 & 8.74 & 9.05 & 9.70 \\
\hline $\begin{array}{l}\text { Total suspended solids (TSS), } \\
\mathrm{mg} \mathrm{dm}^{-3}\end{array}$ & $<2.5$ & $<2.5$ & $<2.5$ & 18.9 & 21.1 & 5.5 \\
\hline $\begin{array}{l}\text { Total organic carbon (TOC), } \\
\mathrm{mg} \mathrm{dm}^{-3}\end{array}$ & 13.27 & 9.33 & 8.67 & 7.60 & 8.07 & 7.87 \\
\hline $\begin{array}{l}\text { Biochemical oxygen demand } \\
\text { (BOD) } \mathrm{mg} \mathrm{dm}^{-3}\end{array}$ & 18.3 & 13.3 & 12.4 & 10.6 & 11.1 & 11.4 \\
\hline $\begin{array}{l}\text { Chemical oxygen demand } \\
\text { (COD) } \mathrm{mg} \mathrm{dm}^{-3}\end{array}$ & 29.9 & 23.9 & 22.9 & 18.7 & 19.5 & 21.1 \\
\hline $\begin{array}{l}\text { Total phosphorus (Ptot), } \\
\mathrm{mg} \mathrm{dm}^{-3}, \text { mean } \pm \text { standard } \\
\text { deviation }\end{array}$ & $0.013 \pm 0.001$ & $0.011 \pm 0.008$ & $0.023 \pm 0.001$ & $0,019 \pm 0.002$ & $0.033 \pm 0.003$ & $0,021 \pm 0,024$ \\
\hline $\begin{array}{l}\text { Dissolved ortho-phosphorus } \\
\left(\mathrm{P}^{-} \mathrm{PO}_{4}\right), \mathrm{mg} \mathrm{dm}^{-3}, \text { mean } \pm \\
\text { standard deviation }\end{array}$ & $0.004 \pm 0.002$ & $0.002 \pm 0.000$ & $0.005 \pm 0.002$ & $0.002 \pm 0.002$ & $0.003 \pm 0.003$ & $0.002 \pm 0.001$ \\
\hline $\begin{array}{l}\text { Nitrate nitrogen }\left(\mathrm{N}-\mathrm{NO}_{3}\right) \\
\mathrm{mg} \mathrm{dm} \\
\text { deviation }\end{array}$ & $1.730 \pm 0.049$ & $0.009 \pm 0.003$ & $0.008 \pm 0.001$ & $0.039 \pm 0.015$ & $0.003 \pm 0.001$ & $0.006 \pm 0.003$ \\
\hline $\begin{array}{l}\text { Ammonium nitrogen ( } \mathrm{N}-\mathrm{NH} 4) \text {, } \\
\mathrm{mg} \mathrm{dm}^{-3}, \text { mean } \pm \text { standard } \\
\text { deviation }\end{array}$ & $0.142 \pm 0.011$ & $0.069 \pm 0.072$ & $0.116 \pm 0,007$ & $0.145 \pm 0.009$ & $0.122 \pm 0.008$ & $0.092 \pm 0.026$ \\
\hline $\mathrm{Ca}, \mathrm{mg} \mathrm{dm}^{-3}$ & - & - & 107 & - & - & 118 \\
\hline Chlorophyll a, (chl-a), $\mu \mathrm{dm}^{-3}$ & 2.16 & 5.79 & 3.81 & 2.85 & 3.32 & 4.56 \\
\hline $\begin{array}{l}\text { Total phytoplankton } \\
\text { abundance, } 10^{3} \text { ind. } \mathrm{dm}^{-3}\end{array}$ & 150.6 & 350.5 & 593.0 & 120.3 & 230.0 & 610.0 \\
\hline
\end{tabular}

Table 3. Seasonal changes of partial and mean TSI values, at Niwa I and Niwa II basins

\begin{tabular}{|l|c|c|c|c|c|c|}
\hline \multirow{2}{*}{ Parameters } & \multicolumn{3}{|c|}{ Niwa I } & \multicolumn{3}{c|}{ Niwa II } \\
\cline { 2 - 8 } & May & July & October & May & July & October \\
\hline TSI(SD) & 55.1 & 53.2 & 56.6 & 71.5 & 77.4 & 71.5 \\
\hline TSI(chl-a) & 40.9 & 47.8 & 43.7 & 19.2 & 42.3 & 45.5 \\
\hline TSI(TP) & 48.8 & 38.9 & 49.3 & 46.4 & 54.7 & 48.0 \\
\hline TSI(TOC) & $62.0^{*}$ & $55.7^{*}$ & $54.5^{*}$ & $52.5^{*}$ & $53.4^{*}$ & $53.0^{*}$ \\
\hline TSI & 48.3 & 46.7 & 49.9 & 45.7 & 58.1 & 55.0 \\
\hline TSI including TSI(TOC) & $51.7^{*}$ & $48.9^{*}$ & $51.0^{*}$ & $47.4^{*}$ & $56.9^{*}$ & $54.5^{*}$ \\
\hline TSI mean & \multicolumn{3}{|c|}{58.3} & & \multicolumn{4}{c|}{$52.9^{*}$} \\
\hline TSI mean including TSI(TOC) & \multicolumn{3}{|c|}{$50.53^{*}$} \\
\hline
\end{tabular}

trophy within reservoirs, as it was design-based on clear water, stratified lakes [Dunalska, 2011].

\section{DISCUSSION}

Seasonal changes in physicochemical, biological and phytoplankton parameters allowed for the preliminary assessment of the trophic status of the Niwa Reservoir (comprised of both the
Niwa I and Niwa II basins), as well as the identification of its primary factors. In spite of the lack of a direct hydrological connectivity of the Niwa I and Niwa II, as well as the differences in their water supply and morphometry, the waters of both basins exhibit many common characteristics. This resulted from the geochemical catchment and basin characteristics: the presence of carbonate bedrock (resulting in high conductivity, reaction and calcium concentration of waters) and 


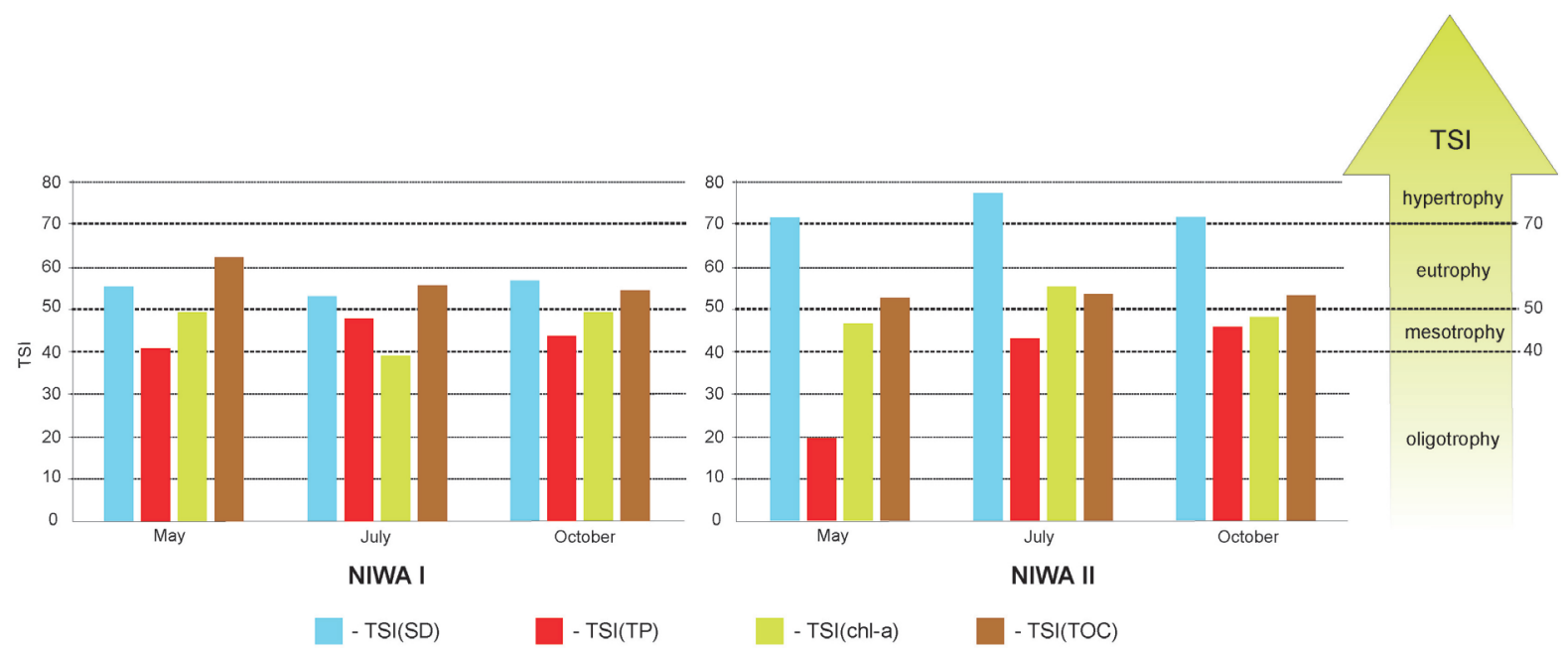

Fig. 4. Seasonal changes of TSI partial values of Niwa I and Niwa II basins

peat substrate (responsible for the elevated concentrations of total organic carbon derived from the catchment humic substrate, and, in the case of Niwa I, also from the bottom of the basin).

Despite the agricultural land use of the catchment, which is potentially a source of high loads of the biogenic salts, elevated nitrate values were only found in spring, in the refilling of the Niwa I basin with the Lepietucha-sourced waters. The absence of an analogous peak of nitrate concentrations in the Niwa II basin may be due to different supply regime, lower water exchange or an effective mechanism of nitrates withdrawal from the water column.

The mean value of the TSI points to the mesotrophy of Niwa I and the eutrophy of Niwa II, which, however, should be discussed in the context of the differences in partial TSI indices carrying additional valuable information on the functioning of the ecosystem in terms of the conditions of the primary production [Szczykowska et al. 2015]. These variations may point to the early stage of the reservoir development and the role, especially in Niwa II, of the abiotic factors in restraining the phytoplankton development. Although the values of the partial TSI indicate meso-, eu- or even hypertrophy (Fig. 4), the overall tropic status should be assessed as being mesotrophic. This is confirmed by the low phytoplankton abundance and taxonomic structure, as well as the biomass content expressed as chlorophyll-a concentration.

The TSI(SD) component in the case of the Niwa Reservoir is a responsive to the mineral turbidity and the presence of dissolved organic carbon, therefore it raises the average value of the
TSI, thus, it should be excluded [Szczykowska et al. 2013]. In the case of Niwa II basin, the mineral turbidity clearly reduces water transparency, hence it inhibits the development of phytoplankton. The chemical fixation of the phosphorus by calcium in the form of apatite also contributes to the decrease of the amount of phosphorus available to phytoplankton [Bartoszek, 2007]. The complexation of phosphorus by humic substances plays a similar role, which may be an issue within the Niwa I basin [Tipping, 2002].

\section{CONCLUSIONS}

Our research shows that the early assessment of the trophic status of the small retention reservoir as based on a set of TSI indices, is a simple method and provides valuable information on the state and functioning of the ecosystem. Based on the in-depth analysis of the partial indexes, we conclude that:

1. Values of calculated partial components of TSI show high variation, which result from the specific characteristics of both basins of the Niwa Reservoir.

2. In regard to trophy assessment, TSI(TP) and TSI(chl-a), as well as phytoplankton abundance and composition are most reliable. These elements all point to the mesotrophy of the Niwa I basin. For the Niwa II basin, only the slightly elevated TSI(TP) value suggest eutrophic conditions.

3. The overall qualitative and quantitative structure and concentration of chlorophyll-a of the 
phytoplankton communities is typical of this type of mesotrophic aquatic ecosystem, and it does not indicate high eutrophication.

However, despite the current low trophic status, due to the high instability of biocenosis in this type of aquatic ecosystems (shallow water reservoirs with agricultural catchment being at an early stage of operation), the negative phenomenon of rapid eutrophication cannot be ruled out, and, therefore, further monitoring is needed.

\section{REFERENCES}

1. Bartoszek L. 2007. Phosphorus release from bottom sediments. Zeszyty Naukowe Politechniki Rzeszowskiej. Budownictwo i Inżynieria Środowiska, 5-19. (in Polish)

2. Carlson R.E. 1977. A trophic state index for lakes. Limnology and Oceanography, 22(2), 361-369.

3. Carlson R.E. 1991. Expanding the trophic state concept to identify non-nutrient limited lakes and reservoirs. In: Carpenter, L., Ed., Enhancing the states's lake management programs, North American Lake Management Society, Chicago, 59-71.

4. Cooke G.D., Welch E.B., Peterson S., Nichols S. A. 2005. Restoration and management of lakes and reservoirs. CRC Press.

5. Dunalska J.A. 2011. Total organic carbon as a new index for monitoring trophic states in lakes. Oceanological and Hydrobiological Studies, 40(2), 112-115.

6. Dunalska J. A., Wiśniewski G. 2016. Can we stop the degradation of lakes? Innovative approaches in lake restoration. Ecological Engineering, 95, 714-722.

7. Lee Y., Kim J. K., Jung S., Eum J., Kim C., Kim B. 2014. Development of a water quality index model for lakes and reservoirs. Paddy and Water Environment, 12(1), 19-28.

8. Pawlik-Skowrońska B., Toporowska M. 2011. Blooms of toxin-producing Cyanobacteria - A real threat in small dam reservoirs at the beginning of their operation. Oceanological and Hydrobiological Studies, 40(4), 30-37.

9. Pęczuła W., Suchora M. 2011. Analysis of causes of poor water quality in water-retention reservoir in Kraśnik in the first years of its functioning. Przegląd Naukowy Inżynieria i Kształtowanie Środowiska, 54, 321-332 (in Polish).

10. Popek Z., 2015. Water restoration. [In] Gabulewski K., Mosiej J., Popek Z., Inżynieria Krajobrazu. SGGW. 104-106 (in Polish).

11. Regulation of the Minister of Environment of 11 February 2004 on the classification for presentation of the status of surface waters and groundwaters, the method of monitoring and interpretation of results and presentation of the status of these waters (in Polish).

12. Siemieniuk A., Szczykowska J., Wiater J. 2016. Eutrophication as a priority issue of water quality in small retention reservoirs. Journal of Ecological Engineering, 17(3).

13. Szczykowska J., Siemieniuk A., Wiater J. 2013. Environmental problems of small retention reservoirs of Podlasie. Ekonomia i Środowisko, 4 (47), 234-244 (in Polish).

14. Szczykowska J., Siemieniuk A., Wiater J. 2015. Diversity of the TSI indicators of the middle-forest small retention reservoir. Journal of Ecological Engineering, 16(5).

15. Tipping E. 2002. Cation binding by humic substances, Vol. 12. Cambridge University Press.

16. Utermöhl H. 1958. The improvement of quantitative phytoplankton analyses - methods. (Zur Vervollkomnung der quantitativen PhytoplanktonMethodik). Verhandlungen des Internationalen Verein Limnologie, 9, 1-38 (in German).

17. Yentsch C.S., Menzel D.W. 1963. A method for the determination of phytoplankton chlorophyll and phaeophytin by fluorescence. In Deep Sea Research and Oceanographic Abstracts, 10, (3), 221-231.

18. Zedler J.B. 2003. Wetlands at your service: reducing impacts of agriculture at the watershed scale. Frontiers in Ecology and the Environment, 1(2), $65-72$.

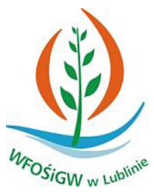

Pracę dofinansowano ze środków Wojewódzkiego Funduszu Ochrony Środowiska i Gospodarki Wodnej w Lublinie. 